\title{
CIDADANIA E DIREITOS HUMANOS NA FORMAÇÃO UNIVERSITÁRIA
}

JOSÉ VAIDERGORN

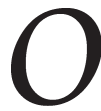

ensino de conteúdos de cidadania e de direitos humanos tem sido enfatizado, como parte dos temas transversais propostos nos Parâmetros Curriculares Nacionais ( $\mathrm{PCN})$, principalmente no ensino básico brasileiro (nos níveis fundamental e médio). Nas diversas disciplinas, propõe-se a introdução de diferentes abordagens de temas de tratamento por vezes difíceis, como as discriminações étnicas, culturais, religiosas, sociais, sexuais e físicas, ou de outros mais abstratos, como o exercício da cidadania de uma forma ativa, em uma condição de quase marginalidade social. Embora sejam aspectos relevantes para a formação dos estudantes, cabe verificar como os professores se apropriam destes conteúdos e de que maneira os desenvolvem, por vezes em situaçóes opostas à que se pretende promover.

Sem dúvida, a presença de tais conteúdos na educação formal é um avanço, se for comparado com o que se pretendeu disseminar como "cidadania" no período em que vigorou a infame Educação Moral e Cívica no ensino brasileiro, criada pelo governo autoritário em 1969 (Decreto-Lei n. 869) e extinta apenas em 1993. Na época, “direitos humanos" eram postos como arma de subversão ao regime, um risco à normalidade institucional da ditadura, por ser argumento de defesa dos opositores perseguidos, presos e torturados, apesar do Brasil ter sido signatário da Declaração Universal dos Direitos Humanos de 1948. Já a cidadania, que antes de 1964 aparecia na educação de

Doutor em Educação e professor do Departamento de Ciências da Educação e do Programa de Pós-Graduação em Educação Escolar da Universidade Estadual Paulista (UNESP, campus de Araraquara). E-mail: vaidergorn@gmail.com 
maneira quase metafísica (na forma de um civismo já afastado de seu potencial transformador das conquistas revolucionárias francesas), tornou-se um discurso ajustado a um comportamento modelado nos ideais obscurantistas convergentes da direita política, dos católicos conservadores e dos militares disseminadores da Doutrina de Segurança Nacional. O fim do regime autoritário, com a instauração de um regime democrático, passou por um processo de restauração do sentido original de cidadania e de direitos humanos - embora um longo caminho ainda tenha que ser trilhado para que ambos possam ser reconhecidos em sua plenitude.

O conceito clássico de cidadania remete ao muito citado capítulo "Cidadania e classe social", do livro de T. H. Marshall, Cidadania, classe social e "status", onde o autor, a partir de um referencial basicamente europeu, distingue três direitos aparecidos em tempos sucessivos: os direitos civis, do século XVIII, os direitos políticos, do século XIX, e os direitos sociais, do século Xx. Tal tipologia ainda é válida para efeitos didáticos, embora com o tempo o conceito tenha se ampliado, incluindo a cultura, a economia, bem como os direitos coletivos e difusos e outros mais polêmicos, como a diversidade sexual.

Tem-se, então, entre outras, uma forma escolar de disseminar os valores de cidadania e direitos humanos, idealmente fundados na tolerância. Não cabe, aqui, avaliar o fracasso ou êxito desta maneira de trabalhar conteúdos tão importantes. Trata-se, sim, de verificar de que forma os professores de ensino básico têm, em sua formação no nível universitário (ou em cursos de aperfeiçoamento), o contato com os conteúdos de cidadania e, sobretudo, de direitos humanos, por estarem em uma situação privilegiada para a disseminação destes valores entre os estudantes. Algumas carreiras possuem tais teores como matéria de estudo, nos cursos de Direito, Ciências Sociais, Filosofia, Teologia etc., o que é diferente de tê-los como conteúdo curricular de educação em direitos humanos. É saudável, pois, que surjam propostas de conteúdos a serem inseridas no ensino universitário, seja na formação de licenciados, seja como proposta de promoção e construção de uma cultura onde os direitos humanos não sejam apenas uma referência teórica longínqua.

Já há uma produção voltada para os conteúdos de cidadania e educação em direitos humanos dirigida ao ensino universitário. Podemse citar, como exemplo, duas obras especificamente dirigidas para este 
fim. A primeira delas, Educação em direitos humanos: temas, questōes e propostas (Sacavino \& Candau, 2008), trata das atividades desenvolvidas pela organização não governamental Novamerica, que tem como propósito desenvolver o Programa Direitos Humanos, Educação e Cidadania, promovido pela Rede Interinstitucional Educação em Direitos Humanos, Cidadania e Democracia.

Entre os textos do livro, há o capítulo "Educação em direitos humanos e formação de professores/as" (p. 73-92), de Vera Maria Candau, que trata, como indica o título, da formação de professores. A autora situa no texto o desenvolvimento da educação em direitos humanos na América Latina, que, de uma forma geral, é bem recente e relaciona-se mais às práticas de educação popular e não formal e de militantes dos direitos humanos. Em alguns países, Brasil incluído, esta educação vem se afirmando no âmbito da educação formal, embora sofrendo com as mudanças da gestão pública. Um aspecto relevante apontado pela autora é que os valores do conservadorismo neoliberal, revestidos de uma aparência modernizadora e predominantes na regiáo a partir do final da década de 1980, são incorporados como uma nova forma de cidadania pela população, dificultando a ampliação da democracia, ainda de baixa intensidade, só exercida na repetição periódica das eleiçôes. Ao mesmo tempo, a autora cita que a educação em direitos humanos vem se "alargando" (sic) e entrando nas escolas, mesmo esbarrando nos currículos rígidos.

Torna-se necessário, então, introduzir o tema "direitos humanos" na formação dos professores (p. 83). Como exemplo, a autora apresenta duas experiências de formação de professores em conteúdos de direitos humanos. A primeira remete à formação continuada desenvolvida pela ONG Novamerica, através de três ciclos de oficinas, de fundamentação dos direitos humanos, de aprofundamento em temas como currículo, seleção cultural, relações de poder e de trabalho, avaliação, conflitos e violência na escola e de enriquecimento, abordando ainda temas como relaçōes de gênero, raça, diversidade cultural, preconceito e discriminação, meio ambiente etc., sempre referidos à realidade escolar. A avaliação, segundo a autora, tem sido bem positiva, tendo já se produzido material didático para uso com estudantes.

A segunda experiência refere-se à introdução de disciplina eletiva sobre direitos humanos em cursos de licenciatura, na USP (Cátedra 
Unesco de Educação para a Paz, Direitos Humanos, Democracia e Tolerância) e na PUC-Rio. A autora descreve a disciplina desta última, organizada em torno de três grandes unidades, que tratam dos fundamentos e contextos dos direitos humanos, da análise de documentos internacionais e nacionais que são referências para os direitos humanos e para a discussão de temas atuais voltados para a escola.

Com uma pretensão diferente, o livro Educação em direitos humanos na formação universitária: textos para seminários (Cardoso, 2009) traz uma proposta de inserir o tema direitos humanos na formação universitária de maneira sistemática, através de conteúdos voltados a cada uma das áreas de formação acadêmica. A coletânea foi produzida pelo Observatório de Educação em Direitos Humanos da UNESP, sediado na Faculdade de Arquitetura, Artes e Comunicação, em Bauru, e apresenta, neste primeiro volume, dez textos destinados a diferentes cursos: Filosofia, História, Sociologia, Política, Educação, Comunicação, Saúde Pública, Biologia, Direito e Relações Internacionais. Embora desiguais (o que é absolutamente normal em uma obra com tal intento), os capítulos fornecem uma estimulante possibilidade de desenvolver, a partir do interesse dos docentes e alunos, uma abertura para a importância dos direitos humanos no contexto da profissão escolhida. Podese buscar a superação, assim, da alienação que o sistema de ensino superior, cada vez mais tecnificado e mercantilizado, vem desenvolvendo em lugar do pensamento crítico e do conhecimento científico, antes privilegiados nesta etapa do ensino.

\section{Referências}

CARDOSO, C.M. (Org.). Educação em direitos humanos na formação universitária: textos para seminários. Bauru: UNESP/OEDH; FAAC; Cultura Acadêmica, 2009.

MARSHALL, T.H. Cidadania, classe social e "status". Rio de Janeiro: Zahar, 1967.

SCAVINO, S.; CANDAU, V.M.F. (Org.). Educação em direitos humanos: temas, questões e propostas. Petrópolis: DP et Alii, 2008. 